\title{
COVID-19 and Health Care
}

\author{
Sarvdeep S Dhatt
}

Journal of Postgraduate Medicine, Education and Research (2020): 10.5005/jp-journals-10028-1388

The impact of the coronavirus disease-2019 (COVID-19) pandemic is being felt across all aspects of life, heralding the onset of clear and irreversible changes to come. Despite the full backing of governments and communities, public and private healthcare systems are fighting an uphill battle against a largely unknown enemy, while also coping with the lack of adequate personnel and resources. Still in spite of tremendous research being carried out everywhere, there is still no clarity on it, and with the mutating virus, we are still I believe in the dark on many aspects.

Coming to COVID-19 and the Indian Healthcare System, it will be fair to say that we were unprepared. Media reports reveal that there is one government doctor for every 10,189 people in India, whereas the World Health Organization (WHO) recommends a ratio of 1:1,000, and this means a deficit of 600,000 doctors; with regard to nurses, the shortage is about 2,000,000. Regarding ventilators, media reports also say that the country currently has around 40,000 , whereas the requirement may be $80-100$ times that number. The healthcare allocation in the country's union budget for the year 2020-2021 is below 1.5\% of country's GDP and falls short of the target spending of $2.5 \%$ of GDP. While the 2017 healthcare policy of the government mandates a minimum of two beds per 1,000 people, the number of hospital beds available in the country for 1,000 people is only 0.7 , according to World Bank data. Further, according to reports, India ranks 184th out of 191 in terms of GDP percentage spend on healthcare. These figures give us a grim picture of the challenges the country faces in ensuring the health of the people; COVID-19 is only exasperating the situation.

The one good thing that is caused by COVID-19 is Innovation. According to the Harvard Business School, "amidst these massive
Department of Orthopaedic Surgery, Postgraduate Institute of Medical Education and Research, Chandigarh, India

Corresponding Author: Sarvdeep S Dhatt, Department of Orthopaedic Surgery, Postgraduate Institute of Medical Education and Research, Chandigarh, India, Phone: +919815126600, e-mail: drsdhatt@gmail. com

How to cite this article: Dhatt SS. COVID-19 and Health Care. J Postgrad Med Edu Res 2020;54(3):77.

Source of support: Nil

Conflict of interest: None

disruptions, a combination of short- and long-term innovation responses can provide a ray of hope for businesses." Greater use of robotics, artificial intelligence, and automation will put the regulatory and liability systems of many countries to the test. They will also affect employment, wages, and union negotiations. Widespread use of temperature screening and tracing of people's physical movement and health status will generate debates on privacy and data protection. Another positive has been the impact of lockdown on air pollution, sound pollution, and greenhouse gas emissions. Perhaps, the biggest positive emerging from this crisis, though, is the realization that we humans are capable of global and collective action, and this has given hopes to billions of people worldwide.

Robert Frost's poem, "Stopping by Woods on a Snowy Evening" is apt for our current scenario where he sums it all up by saying:

"The woods are lovely, dark and deep, But I have promises to keep, And miles to go before I sleep, And miles to go before I sleep."

(c) The Author(s). 2020 Open Access This article is distributed under the terms of the Creative Commons Attribution 4.0 International License (https://creativecommons. org/licenses/by-nc/4.0/), which permits unrestricted use, distribution, and non-commercial reproduction in any medium, provided you give appropriate credit to the original author(s) and the source, provide a link to the Creative Commons license, and indicate if changes were made. The Creative Commons Public Domain Dedication waiver (http://creativecommons.org/publicdomain/zero/1.0/) applies to the data made available in this article, unless otherwise stated. 